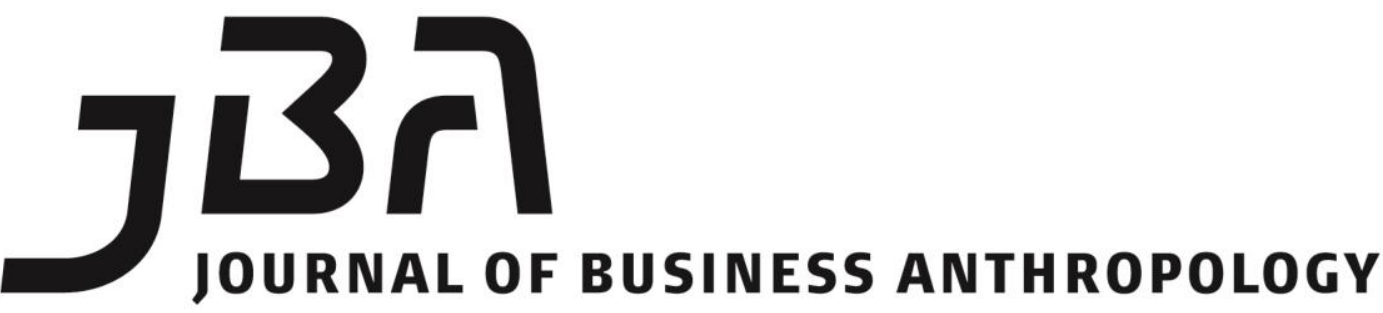

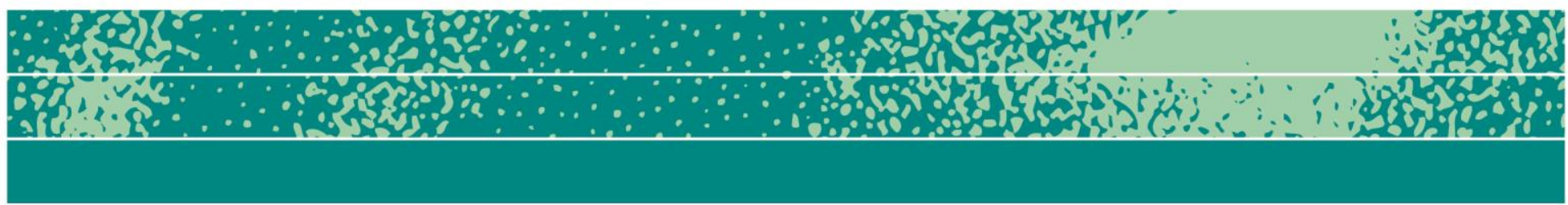

\section{Language, Power and the Liminal: A Korean Translator/Interpreter's Role in Shaping Identities in the London (UK) Business Community}

Fiona Moore

\begin{abstract}
The impact of translators and interpreters on transnational business is not often considered, and yet, they have the ability to ensure the success or failure of communication during transnational business ventures, and to shape and define the identities of organisations. As part of a wider ethnographic study of the Korean community in London (UK), I focus on the case of "Mrs Park," a professional Korean interpreter and translator, and the ways in which she mediates between Korean and non-Korean organisations. We conclude that to understand the roles language and identity play in transnational business, the position of the translator/interpreter as a cultural intermediary must be taken into account.
\end{abstract}

\section{Keywords}

Translators, Korea, identity, language, power, liminal
Page 1 of 24

JBA 4(1): 82-105

Spring 2015

(C) The Author(s) 2015 ISSN 2245-4217

www.cbs.dk/jba 
Translators and interpreters wield considerable power in international business, as they interpret not only language, but identity and information, between different parties in transnational business transactions. They serve as "cultural intermediaries" (Negus 2002), liminal individuals, positioned between two groups, but who, given the connections structuralist anthropology has drawn between language and social construction (Levi-Strauss 1974; Gumperz 1974), have the power to define and shape the identities of businesses and communities in the eyes of both outsiders and their own members (Blenkinsopp and Pajouh 2010). Despite this, the importance of such linguistic mediators is often overlooked in the academic and practitioner literature on international business. Through the case of "Mrs Park," a Korean translator and interpreter in London, we will explore the way in which she engages in discourses of power in the process of mediating between parties, and argue that such liminal individuals play a key, if unrecognized, role in shaping identities in transnational business.

This article adds to the international business anthropology literature, which tends to be heavily grounded in the wider IB research tradition, in that, firstly, we consider language and identity through the lens of a seldom-considered vector, namely, the professional translator and interpreter. While there have been articles on language and identity in transnational business (Holden 2002; Holden and von Kortzfleisch 2004; Brannen and Doz, 2010) on the role of translators in organizations (Angelili 2004), and on language and power in and between different cultures (Parkin 1984; Gumperz 1974), there has been little work examining the actual role of the translator or interpreter as a cultural intermediary in a transnational business setting. Secondly, the paper draws on the literature on discourse in business to examine the role of language in power relations in transnational organizations, byh exploring translation as a social act embedded in discourses of knowledge and power. Finally, we look at the power relations involved in the activities of translators and interpreters, hired by corporations on an ad-hoc basis as external contractors, but nonetheless in a key position to mediate across borders on behalf of international businesses. We therefore contend that, to properly analyse the role of language and identity in transnational business, we need also to consider the role and status of the agents mediating the linguistic exchanges, as explored in more traditional anthropology.

\section{Translation, knowledge and power}

It has frequently been noted that language is important for businesses, including transnational businesses, in subtle and complicated ways (Harzing and Feely 2008; Piekkari and Zander 2005; Usunier 2010; Welch, Welch and Piekkari 2005). Furthermore, it has also been noted-for instance by Piekkari and Zander (2005)-that we cannot 
separate language, as parole, from its context: namely, its use by specific people, in specific ways, at specific times. The literature on discourse goes even further, arguing that power relations in organisations are subject to complex dialectics which are embedded in discourses within the organisation (e.g. Merilainen et al. 2004, Thomas and Linstead 2002), while the literature on storytelling in organisations also highlights the complexities of linguistic phenomena in allowing people to make sense of their organisations (see Czarniawska 1997; Gabriel 2000). Language is thus a culturally embedded, individual phenomenon which affects the way in which business is conducted across borders.

One of the most visible ways in which language affects transnational business is translation and interpretation. Brannen and Doz observe that "companies... employ the services of specialized interpreters precisely so that they don't get lost in translation" (2012: 77), meaning that the social act of translation has an impact on the success of transnational business ventures. Holden (2002) draws parallels between cross-cultural business ventures and translation, arguing that both include similar problems, such as interference, misunderstandings, and the lack of equivalent terms or concepts $(244-5 ; 266-8)$.

Furthermore, Holden argues that translators not only interpret the language, but also the cultural traits which go with it, giving them an unacknowledged but crucial role in the social dynamics of transnational business ventures, and bringing in the issue of power relations (2002: 244-5). This is illustrated by Blenkinsopp and Pajouh (2010) who use the example of a single untranslatable/emic Farsi word, tarouf, to explore the responsibility of translators to convey the full meanings of words and the problems which can arise in doing so. Elsewhere, Holden and von Kortzfleisch argue that translation is "a kind of knowledge conversion which seeks to create common cognitive ground among people, among whom differences in language are a barrier to comprehension" (2004: 129). Angelili (2004) identifies five key aspects to the translator's role-alignment with the parties; establishing trust; communicating affect as well as message; explaining cultural gaps/interpreting culture as well as language; and establishing communication rules-which highlight the knowledge transfer and cross-cultural management aspects of the profession. As such, they are, in Williams' (2010) words, boundary spanners: individuals who mediate between an organisation and its outside environment, and/or between organisations. Communicative competence, and the ability to translate, are thus an integral part of the transfer of knowledge and the shaping of identity, and translators play a distinctive role as mediators in transnational business environments.

However, the more outcome-focused tradition of IB studies means that it is not often considered that transnational interaction of this sort also involves power relations. Fairclough (1989) explores the influence of power in language, discussing the ways in which ethnic minorities are 
systematically marginalised through the ways in which narratives are culturally and ideologically shaped (49). This has been examined in the literature on discourse in organisations, for instance de Graaf (2001), Merilainen et al (2004), and Holmer-Nadesan (1996), who consider the emergence of power structures in organisations through discourses of hierarchy, gender, patriarchy and class. Some literature also exists in this area which is specific to translators: Edwards, Temple and Alexander (2005), Mikkelson (2001), and Rudvin (2004) all consider the ethics of the translation professions regarding the power aspects of the translator's role: "when negotiating complex interpersonal group relationships with the other interlocutors, the interpreter might not be free to 'simply translate', especially in a hierarchical private or public institutional relationship" (Rudvin 2004: 15).

In organisation studies, Moore (2006) considers how communication is instrumental in power relations between expatriate and locally hired staff in a transnational banking organisation, and Krakel's 2005 paper looks at the benefits, for individuals and groups, of withholding knowledge in organisations. MacDonald and Piekkari consider how individual networks, connections and power relations in and outside of a particular company affect the transfer of knowledge (2005). In a study of merging organisations, Vaara, Tienari, Piekkari and Santti (2005) argue that "corporate language policies should not merely be treated as a practical means to solve inevitable communication problems; rather, they should be viewed as exercise of power" (596). They also argue that "the traditional view emphasizes that specific discourses and practices empower particular parties and disempower others." From a more radical perspective, languages and discourses can also have power over people in ways that are not obvious in everyday social interaction.

One can also take a postmodern view and see language, knowledge and power as intertwining elements in the social construction of identities and subjectivities" (597). Piekkari and Zander note that language always has connotations of power relations, and that "using English as a shared language may lead to false assumptions of a common context or similar preferences" (2005: 7). Henderson (2005: 67) argues that "language-related issues can impact negatively on interpersonal relations, trust, and the working atmosphere," while Harzing and Feely (2008: 51) also see language as a key source of friction and conflict. In business, therefore, literature indicates that language is tied up with micropolitical power relations, making the status of the translator, or interpreter, crucial, as she is the vector of the discourses of power in the organisation.

However, the role of the interpreter, and the power relations involved in their professional activities, are seldom considered in practice. Their translations are taken as a more or less literal interpretation of what has been said, while who the interpreter is, their relationship with 
the community, and how their role affects the way the parties involved in the cross-cultural encounter, are seldom considered (Rudvin 2004: 63). This is in line with Marschan-Piekkari, Welch and Welch's observation that language is a source of power which can allow or block access to key information through the use of intermediaries for communication (1999). Sanyal, Napier and Smith (2007)'s case study shows how translators have power over the success or failure of a business venture. The translator thus has a potentially important role with regard to transnational business, in that s/he has the power to give or to withhold information about companies and environments.

However, language and translation are also used in the definition and construction of organizational identity. It has long been noted by anthropologists that language is related to cognition and categorization (Gumperz 1974), and therefore affects the way in which people define their social universes (Levi-Strauss 1974). Cohen has specifically detailed how language can be used as a means of defining group identity, most notably in The Symbolic Construction of Community (1985). Cohen, drawing on earlier work by Bloch (1974) and Sperber (1974), proposes that membership in social groups is defined by, and expressed through the use of, commonly held ideas, concepts and stories expressed through language. Although the interpretations given to these items vary between individuals, Cohen argues, key aspects are shared by all group members, due to their common experience of socialisation. Language is thus seen as key to the construction of group identity.

Language has also been considered in anthropology as a site through which group identity is negotiated and reconstructed. Parkin (1984) considers how oratory can be used not only as a means of persuasion or rhetoric, but also of negotiation and of working through conflict in society. Denison describes how language is used by members of the trilingual central European community of Sauris to symbolise changes in context, using different languages in the public and in the private domain (1971), while Cook-Gumperz and Gumperz (2002) explore ways in which culturally-based differences in linguistic interaction affect performance by non-English speakers in gatekeeping interviews in English-dominated organizations. The anthropological literature thus presents language as connected with culture, identity and selfpresentation, and linguistic acts as important sites for negotiation.

This has also extended into the literature on business discourse (see, for instance, Dhanania and Gopakumaran 2005, Holmer-Nadesan 1996). Rudvin (2004), with specific regard to the translation profession, considers the complex ways in which ethnicity, language and professional status work together in the definition of identity. Harzing and Feely (2008: 52) note that in organizations language is also tied up with identity, in that it affects the categories through which people express their own identities and classify others. Peltokorpi (2010) also considers 
the way in which language and cultural competence are intertwined for expatriates. Translation, and the power relations involved in it, therefore must also contribute to the construction of organisational identity.

In this context, interpreters can be seen as what Bourdieu termed "cultural intermediaries" (Nixon and DuGay 2002). Cultural intermediaries are generally defined as people who occupy a social position or status which allows them to interpret the meaning of a particular item or practice to a given audience, such as PR executives, consultants, lawyers and others (Nixon and DuGay 2002; Negus 2002). Interpreters, traditionally, are also frequently liminal individuals: that is to say, people who are neither one thing nor the other, a mix of different, normally separate categories (van Gennep 1960: 20). Liminal beings have the power to disturb through their boundary-crossing nature, to cause people to think about the separate categories represented, and the boundaries between them, thus helping them to define what is considered to be "normal" (Douglas 1966: 54-5). In the case of national and ethnic identities, liminal people often mediate between different social groups, such as Burton, Dyson and Ardener's bilingual women (1993). Translators, being liminal people who mediate between language and culture (as in Edwards et al. 2005), thus occupy positions through which the identities of groups, such as organizations, are defined by a process of knowledge transfer, enabling their role as Bourdieuian cultural intermediaries.

Although recent studies have indicated that language and discourse play a key role in transnational business activity and organizational identity development, so far-as I have mentioned-little attention has been paid to the role of the interpreter, and to the crucial role which such individuals can play as cultural intermediaries. We shall here develop the earlier studies by exploring the dynamics of transnational business through translation and interpretation.

\section{Methodology}

The fieldwork on which this paper is based was part of a twelve-monthlong intermittent study undertaken in 2006 and 2007, scheduled around the researchers' teaching and administrative duties, collecting narratives from expatriates and entrepreneurs in the Korean business community of New Malden, London. The project was conducted by three researchers, one Korean and two non-Korean, although the bulk of the data-gathering and preliminary analysis on the "Mrs Park" case was done by a single team member. The aim of the project was to investigate the role of ethnic, national and gender identity in network-building and the formation of business communities.

The project was based around in-depth life-history interviews, which were undertaken with twelve individuals, who were interviewed 
for at least two hours each: once informally over lunch and once formally. Some interviews lasted for longer, and some participants were reinterviewed. Shorter, informal interviews were also undertaken with others. Participant observation was undertaken in the community, as one of the research team, a non-Korean, lived in New Malden, and another, though not a New Malden resident, was a Korean who was involved in Korean community activities.

Mrs Park was interviewed for two hours, once by three researchers and once by a single researcher, and briefly re-interviewed over the telephone, by a single researcher. Although these data form the core of the paper which follows, the other interviews and the participant-observation data were drawn on to provide context for Mrs Park's experiences and how to analyse them as social activities. Limitations included the fact that the study was, of necessity, conducted intermittently; that only one of the researchers spoke Korean; and, of course, that the study is filtered through the experiences and academic backgrounds of three researchers of different ages, ethnic origins and genders. All names have been changed, and some details have been altered to protect interviewees' identities.

The decision was taken at the outset of the study to employ ethnographic methodologies, particularly the collection of narratives, as it was felt that these could provide useful sources of data and analysis on how people make sense of their organisations, identities and communities (Tsoukas and Hatch 2001), and how people use narratives for the construction of identity and culture (Czarniawska 1997, Holden 2002: Chapter 11). In Czarniawska's words, "narrative is the main form of social life because it is the main device for making sense of social action" (2004:13). Analytical rigor was ensured through having the notes coded by all three team members, and perspectives and interpretations discussed in light of other findings of the project, with the different backgrounds of the researchers providing checks and balances on the different interpretations.

For this paper, we have decided to focus on a single case, following the anthropological literature on the focused case study or life history, which argues that valuable experiential data can be obtained through a study of a single key individual in relation to a community (Clifford 1987), and to consider the perspective which arises from this. While this is an unusual method in the anthropology of business (see Moore 2011), earlier life histories (for instance, Black Elk and Lyon 1990) suggest that viewing a particular group through the experiences of an individual can illuminate aspects of its members' experience, and thus suitable for this case. 


\section{Social background: Mrs Park in the Korean business community}

The principal subject of this paper is "Mrs Park," a professional Korean translator who has settled permanently in London. Although South Korea has been gaining in prominence in the international business literature in recent years (e.g. Lee and Trim 2008, Chun 2009), there is little comparative data on language use and transnational business activities in Korean networks and organisations. Many of the articles which do consider these aspects of Korean business do so in the context of a multigroup study (e.g. Iyer and Shapiro 1999). One of the more comprehensive relevant studies focusing on Koreans specifically is Osman-Gani's study of Korean expatriates in Singapore, in which he notes that the overwhelming majority (89\%) were male (2000: 220), and also that Korean businesses tended to emphasise language training in pre-departure development. Popular business works, such as the Going Global Guide (2003), often state that Korean business culture is very male-focused, and that women tend to occupy lower-status positions. Regarding Korean sojourners, Dana (1999) notes that Koreans tend to settle abroad for the sake of their children's education, returning when that education has been completed, an observation confirmed by several of our interviewees. This provides some context for Mrs Park's case.

Mrs Park is one of the longest established members of London's Korean community. She arrived in the UK in 1981, accompanying her husband, who was then a theology student. She-and later, her husband-began doing translation in the mid-1980s as a way to obtain money to live on. In her own words:

"We had to make a living, but to do any business, you need a capital investment, which we didn't have, because we came here without any money. At the time, there was no Korean software and computers were very rare, this was nineteen... eighty... six, or seven, so we had a portable typewriter (laughs). But after a few months the computers began to come out, you know, Amstrad? Yes, that was a real innovation, and then Korean software came out. It was very basic, but you could type Korean characters into it. But when we first started, there was really very little work: [mostly] interpreting for the immigration, and police, and courts."

The turning point came around the time of the 1988 Olympics in Seoul, when South Korea was achieving a new international visibility, and the Korean community was becoming more established in the UK.

"In 1988 we had just one big job, it was quite important, and at the time we didn't have a computer, but an English friend, she said "oh, come use my computer any time," because she would go to work every day, and so we went into her home to use the computer, and we got Korean software, I don't remember how, maybe we borrowed it. Anyway, somehow we 
managed it, and we translated something like a manual for an aero-ship? [Interviewer: a dirigible?] Yes, (laughing) I didn't know the word!... And then after that I taught Korean at [a college of the University of London]. Through [this college] we got some jobs; at the time people didn't know where to go for a Korean translator or interpreter, they were so rare."

Although Mrs Park herself tends to downplay her subsequent visibility, she and her husband have built up their activities into a thriving small business. Mrs Park is thus well positioned to serve as a cultural intermediary between Korean and British businesses.

\section{Power and negotiation: the various roles of the interpreter}

Mrs Park is able to control access to Korean businesses by outsiders, based on her ability to give or withhold her translation services:

Mrs Park: "The worst is, like, when somebody has a job and [says] 'I want this delivered by yesterday,' and it is very difficult, some jargon or something. They are not very helpful sometimes; we telephone them and e-mail, [saying] 'what is this, what is that, whatever'... Otherwise things are fine, very spaced out, when you have so many jobs rush in you have to turn them down."

\section{Interviewer: "How do you handle that?"}

Mrs Park: "We turn them down, or we find someone else for them."

Mrs Park went on to acknowledge that if a client was known to be difficult, or pay too low a wage for the work, she and her husband would turn the work down. As there are still relatively few Korean translation services in the UK, and for a number of years she and her husband were the only one, this suggests that she was able to use her power as an interpreter to disadvantage clients whom she did not like. The translator thus may be a casual, contract employee of the client, but actually is not as powerless as this relationship might suggest.

There was, in line with Edwards, Temple and Alexander's observations about the role of trust in the interpreting professions (2005), a lot of relationship-building involved in the role of translator:

"There are some [translation] firms that disappear. And that means they are outsourcing [translation work to Korea], but some [translation] agencies are still very loyal.... Two agencies merged: at the old agencies we worked at a certain rate, and the new agency, we didn't know what their rates were, so we worked on a job without even asking the rates, and then [I said] 'when you were A agency, you had these rates, and now you are a new agency, what rates apply?' and 
they were even higher! But they are very loyal."

Mrs Park was also able to build on her reputation in the London Korean community as a means of commanding a higher rate of pay than other translators:

"They say our rate is slightly high, even compared to other Korean translators in the UK; there are only about three or four, so they try to bargain." (laughs).

At the same time, however, she also observed that a number of firms were choosing to outsource translation work to firms in Korea, which were less expensive, suggesting that the translator's role is one involving negotiations, not only in the act of translation, but in acquiring and keeping clients.

This negotiating for power also appeared to prevail among translators:

Interviewer: "So, you mentioned there are only about four or five Korean translators in the UK. Do you all know each other then?"

Mrs Park: "Yes, yes. When we meet each other, we actually recruit each other to work for clients, so we treat each other, yeah. We get on very well."

Interviewer: "Do they recruityou sometimes for jobs?"

Mrs Park: "No, no!" (laughs) "We are the ones who land the big jobs. They refer their clients to us once in a while if they can't handle the work."

Where Mrs Park initially appears to describe fairly egalitarian relations between translators, her second comment makes it clear that there is an informal hierarchy: they are not "recruited" for jobs by other translators, but difficult clients are passed on to them by what she deemed more junior translators. This was significant because the field was becoming more competitive:

[regarding the amount of work she and her husband do in a typical month] "Less than we used to do-I think now maybe more Korean people speak English, or fewer people are coming [to the UK], I don't know, but there is less demand."

The field itself was thus one in which, unofficially, status was attributed, maintained and negotiated, and in which power and competition were significant parts of the landscape, both when acquiring clients and in the actual act of interpretation (see Mikkelson 2001).

Once a good relationship was built up with a client, however, a situation of mutual trust prevailed:

"I think it's because we have built up a sort of trust, because 
we are happy with our job, and they have very good feedback from their clients."

There was, however, creativity involved in maintaining a positive relationship:

"One English customer said 'oh, your interpreting was wonderful!' [I said] 'Well, you don't speak Korean, so how do you know that?' (laughs) 'No, no, no, I could feel it!' Because I was standing just in front of these people when he had to use the whiteboard, and I never realised it, but he said that if he makes this motion (demonstrates) I would do the same thing, looking at him and copying him."

Mrs Park's accounts of her work thus suggest that the translator engages in cross-cultural mediation at all parts of the process: acquiring clients, building relationships with them, acting as a channel for communicating information between clients, and maintaining status vis-à-vis rival translators and/or interpreters.

\section{The translator/interpreter as liminal individual}

\section{Liminality and culture}

Within Korean businesses and the wider Korean community, Mrs Park's role was explicitly liminal. When defining her identity, she set herself and her lifestyle apart from those of "regular Koreans," as in her discussion of why she prefers to live in England:

"It's not so busy, not so hectic, less materialistic, and Korean people are bad, very materialistic. If your next door neighbour changes her car, I have to change mine; if she buys a new wardrobe I have to buy a new wardrobe. We don't have that here."

Unlike Edwards, Temple and Alexander's interpreters, whose jobs and reputations are largely obtained through family and community ties (2005), Mrs Park emphasised that she had few relationships with other Koreans, either in Korea or in the UK, and appeared to explicitly highlight Korean culture as a factor:

"Korean people still believe in [the] Korean way, we have very few friends, very few Korean friends (laughs); I try not to make friends!"

She also sets herself apart from Korean business culture, when asked to describe the Korean community in the UK.

"Very many businesspeople, yes, and some people, I think they are rarer... I know very, very few. So that's what it is. I am not the right person to interview, because I know so little about it!" 
Her narrative about her arrival and settling in the UK also emphasizes the difference she perceived between herself and the "typical" Korean selfdirected expatriate:

"When I first came here 25 years ago we lived in Bristol, and we didn't know many others. And then we moved around, and we moved down here [to London] in 1995, eleven years ago, and there were quite a few Koreans, but there's quite a lot more now."

Significantly, given that residence in and around New Malden was a major point of identity for most Koreans in our interview sample, Mrs Park did not live in the area. Mrs Park does actually have a number of Korean friends and acquaintances, again suggesting that this distance is more a matter of consolidating her liminal identity than anything else. However, even when she discusses her Korean friends, she emphasises the unusual, and transnational, nature of their relationship:

"We are still very good friends with about three families, and she write and we go to see them and they come, it's quite a lot of fun. I made a lot of friends at the school gate, you wait for your child to come out and you meet other mums, I made some quite good friends and we're still in touch, though our children... And when we moved to Islington, there was one Korean family who lived there, for one or two years, but then they moved to Chicago. We are still in touch.... Oh, and... because we came here quite early as theological students, when some new theological students came over, somehow they found us. And they came and visited us, [because] they were colleagues. And after that, we became friends, Korean friends. But after one or two years, they all left."

Unlike other Korean expatriates in our sample, she also made a point of not visiting Korea, except on business or to accompany her daughter:

"In the last 25 years we have been back to Korea only twice. He [her husband] has been there twice on a job; our customer took him for interpreting. In my case, I went home with my daughter once and then two years ago on my own on a job. We have a very good customer in Glasgow, a whisky distillery, and they took me there because they had a very important meeting. They had a Korean interpreter brought by their Korean client, but they didn't like him."

Finally, although a regular churchgoer, she eschews the churches in New Malden in favour of a predominantly non-Korean one elsewhere. Mrs Park thus casts herself as liminal and transnational, distinguishing herself from, and yet belonging to, both groups; this, however, also situates her as a cultural intermediary, able to interpret the two groups to each other by virtue of her status as someone "in between". 


\section{Liminality and gender}

Mrs Park's gender role is also unusual for a Korean woman, as described here:

"In Korea things would be quite different. In Korea, of course, the husband won't go in the kitchen, he won't go shopping. In England, it is different. In England even the businesspeople will help their wives. It's funny, they [Korean expatriates] will do the washing up, help with children, and... But once they go back to Korea they land on Korean soil and change back to the old ways.... And there are times, when you go to interpret, like once I was in court in Birmingham, and I was employed by an English solicitor but his clients were Korean. Three Korean gentlemen.... And you know what they said, when I was right in front of them? Quiet but loud enough for me to hear (stage whispering): "Do you think this woman can do any kind of translation?!" Then the proceedings started and after that they changed their attitude (laughs). But that is the attitude of Korean men."

\section{Interviewer: "Do you get a lot of that from Korean men?"}

Mrs Park: "No, now it is very unusual, but sometimes you get it, you do get it. I think it happened about ten percent, but otherwise, especially slightly older people, otherwise. There was one case where I went to Switzerland to interpret a seminar; it was a business school in Lausanne. And the audience was all Korean journalists (gesturing and grimacing to the general effect of a tough crowd), and one of the Korean journalists actually came up and said, "You are the best interpreter I have ever listened to." We get that now and again. Even the English are very happy with us. They say [interpreters] don't get complete recognition [for their work], but the emotion is there."

In this exchange, Mrs Park highlights, first of all, that the role of women in the Korean expatriate community is more powerful, and gender relations more egalitarian, than in Korea. She distinguishes herself as somebody who plays what Koreans would consider a non-traditional gender role, and takes her success in this role as a point of professional pride. Mrs Park's unusual status allows her to adopt a non-traditional role, and, at the same time, this role highlights that of a "normal" Korean woman.

Mrs Park thus casts herself as liminal-in the sense of not being of the community; of having different experiences of arrival in the UK, of London life, of gender and family relations-in comparison to "normal" Korean expatriates. She positions herself less as a Korean expatriate than as a mediator between the British and Korean contexts. It is this liminality, 
however, that makes her a more effective cultural intermediary in a transnational business context.

\section{Language, power and Korean business}

\section{The use of English and Korean}

In this context, it is worth exploring what bilingualism and language choice mean in the Korean business community in London. It has often been noted in the anthropological literature that bilingualism enables mediation between communities (see Burton, Dyson and Ardener [eds] 1993, Cook-Gumperz and Gumperz 2002), and Peltokorpi (2002) has also noted the connection between second-language ability and intercultural competence in IB. Among the Koreans interviewed, both expatriates and sojourners, proficiency in English was taken as an indicator of integration into the UK, and/or cosmopolitanism. Male expatriates frequently told us that their wives did not learn much English, beyond what they needed to cope with daily life in London, and managed mostly by confining themselves to New Malden, with its prevalence of Korean-owned businesses. If necessary, they recruit husbands and children to perform translation services. As women are frequently cast in the roles of keepers of tradition and community in expatriate groups (see Jeffery 1976), the fact that this core of Korean-speaking, New Malden-resident individuals is female is significant. Here, two symbols of Korean identity-residence in New Malden and a lack of fluency in English-combine to define the core of the community.

However, the use, or lack of use, of English also defines power relations between the expatriate group and the host culture. The case of "Ms Kim," a hairdresser, stands in contrast to that of Mrs Park. Like Mrs Park, Ms Kim is an entrepreneur; unlike Mrs Park, however, she has had some difficulty integrating into London outside of the Korean community. A significant part of this narrative involves her relative lack of fluency in English: her stories about being exploited by customers frequently include a critique of her own language skills, along the lines of "if I spoke better English, I wouldn't have been fooled.” Her English is actually fluent, suggesting that an ability to speak English is taken as a marker of social integration (her problems with non-Korean clients being symbolised by language problems), and also that it forms part of a system of power relations (those who do not speak English well open themselves up to exploitation). This echoes Piekkari and Zander's observation that "equality of languages can never be taken for granted in international companies" (2005: 5) and Chapman, Clegg and Gajewska-Dematteos (2004)'s observation that the one with greater fluency in the language being used has the more powerful position in the conversation. In this context, English is not only the "universal language of business," but also the native language of the host culture, meaning that the Koreans are expected to come to the British, rather than vice versa. 
Moreover, learning Korean was portrayed as a form of transnational engagement, as well as of strength within the Korean community. At the time my second interview with Mrs Park took place, for instance, signs advertising a GCSE (secondary school qualification) in Korean were visible in the New Malden High Street. Mrs Park described it thus:

"I saw it in the Korean paper [in New Malden]. There was a friend who came over with her daughter about thirteen, fourteen years ago, and she started up a small school. She was trying for the Korean GCSE. I don't know if she had anything to do with this because we've lost contact now... Ten years ago I was approached by all sorts of people to help build this GCSE course, but I did not [participate], I have been away from Korea too long... But that should be good."

Mrs Park also speculated, when we were discussing this, that many of the children of Korean expatriates make use of their bilingual skills and their connections to two different cultures, to become themselves culturally liminal individuals, international managers with either Korean or British MNCs, mediating between both cultures-like Goodman's “international youth" in Japan (1993), or the children of German expatriates elsewhere in London (Moore 2007). Korean language learning is thus defined partly as a means of expressing identity, but partly in terms of gaining power, through acting as a cultural intermediary in international business.

The Korean language gains legitimacy as a study option for students, presumably with a view to its use in an international career or to emphasise to their families that they retain a connection to the country of origin, rather than as a language of business in its own right in the British context. The choice of Korean or English therefore has connotations of power relations, and of transnational engagement.

\section{The role of the interpreter}

Mrs Park's definition of herself as apart from the community also, paradoxically, defines the community's norms. Her activities with outsiders, her geographic position outside New Malden, and her choice of English, all mark out what is considered normal for Koreans in London, whether expatriates or immigrants-speaking Korean, living in or near New Malden, and networking with other Koreans-as well as what is normal for English people: living outside New Malden, speaking English, and remaining outside the Korean community. This is borne out by the activities of others in our sample who emphasised their separation from what they saw as the core Korean community. Mrs Park is not ashamed of her Koreanness; indeed, since she makes a living off her Koreanness, this is a part of her business identity. However, her liminal position allows her to operate in both cultures, and mediate them both to each other.

Nonetheless, Mrs Park also appeals to external institutions to 
provide legitimacy. While she is modest about mentioning the high profile of some of her clients, her website contains film clips of her translation activities for the South Korean Embassy, and her personal narrative also mentions the fact that she taught Korean at the University of London for eight years. She describes her students as "businesspeople... and diplomats, and... some [anthropologists]," though adding selfdeprecatingly, "and why they wanted to learn Korean I don't know." Establishing her role as a legitimate interpreter of language and culture thus requires maintaining a balance between signs of inclusion and signs of liminality, both marking the boundaries between groups, while at the same time negotiating the placement of these boundaries.

Mrs Park's position and role within the community, her use of language, and her means of establishing legitimacy thus allow her to negotiate between two social groups, and also to both establish and question the boundaries between them, through the transmission and withholding of different sorts of information. This, again, supports the proposition that liminal individuals in networks and organisations can, by virtue of their liminal status, wield great power through their role as cultural intermediaries. We shall now consider a few implications of Mrs Park's case.

\section{Analysis and conclusions}

The status of the interpreter

Many studies describe the role of the translator and/or interpreter as paradoxical (Blenkinsopp and Pajouh 2010; Edwards, Temple and Alexander 2005; Mikkelson 2001; Rudvin 2004). On the one hand, it is usually taken up by liminal individuals, as was the case for Mrs Park and her husband, who took on their work as students (which was also true for many of the other Korean translators she mentioned). Translation is a fairly common occupation for students, recent immigrants, and other liminal groups with connections to non-native languages and cultures, since it is work which requires little more than knowledge of the relevant languages, and which allows time for other activities (see Edwards, Temple and Alexander 2005). At the same time, however, the translator plays a powerful role in networks and organizations, because of his/her ability to mediate knowledge (Angelili 2004; Blenkinsopp and Pajouh 2010; Rudvin 2004). This was also apparent when conducting field research for this project, when some of the interviews had to be conducted with one of the research team translating for the interviewee, leaving the non-Korean-speakers on the team having to rely on the translator's interpretation of what the interviewee had said, rather than engaging in free interaction with the interviewee. The translator thus potentially has the power to affect the success or failure of a business deal, an interview, or a written work, through how well or how poorly $\mathrm{s} /$ he is able to convey the meaning of the original text, but at the same 
time frequently is in an ambiguous social position, situated between two or more worlds.

However, this is the source of much of the translator/interpreter's power and ability to shape and develop the connections between individuals and businesses. As Douglas notes (1966: chapter 6), liminal individuals are outside the two communities and/or statuses involved, but as such they can also move between them, act as mediators, question them, and define them. Mrs Park's ability to avoid the normal gender restrictions of her community is also part of this. ${ }^{1}$ The translator becomes analogous to the priest or other ritual performer in Bloch's (1974) analysis: s/he tells people what has been said, and mediates its meaning to them, with similar issues regarding trust and confidentiality (Mikkelsen 2001). This study suggests that liminal individuals play a powerful role in networks and organisations, mediating, tacitly or explicitly, between different groups, and thus serving as important cultural intermediaries, an implication which could lead to interesting future research.

\section{Translation as identity-defining activity}

This case also highlights Mrs Park's role in defining symbols of Korean and British identities. This can be seen in the following quote:

"Once I was told off by a very, very high official from Korea. The man for whom I interpreted didn't mind at all, but the high official, he brought lots of his people, and one of them said I was enjoying myself too much, I was too excited. My voice was not proper. But it was a big room! And I enjoyed it actually."

Here, for instance, she mediates differences in what is considered acceptable behavior in both groups: the Koreans finding her style "too excited," but the British subject "not minding." Her unusual gender role also serves to highlight to Korean clients the fact that women's business activities are less circumscribed in Britain than in Korea. In translating for companies such as the Scotch whisky distiller, she would also be mediating the cultural associations of Scotch whisky in the UK vis-à-vis its associations in Korea. She is also, without necessarily being conscious of it, the vector for tacit knowledge about both groups' identities to the participants (Rudvin 2004).

Furthermore, Mrs Park not only mediates identities, but is active in the discursive creation of identity (see Gumperz 1974) about the organisations involved, by introducing her own interpretations and experiences of British and Korean identity into the translation context.

\footnotetext{
${ }^{1}$ It is worth noting that most Korean women in our sample said that they felt they had more freedom in the UK than in Korea, because they were outside the Korean context, thus giving them also a liminal aspect.
} 
Since she is the vector of communication between Korean businesses and their hosts, she helps them to define themselves in the eyes of the British, and vice-versa in the case of British businesses expanding into Korea (supporting literature on the role of language in defining identity in business, for instance Dhanania and Gopakumaran 2005). Companies rely on Mrs Park, and others like her, to define their identities to outsiders, meaning that she has a crucial role in how these companies are perceived in the host culture. The translator thus, as indicated in the anthropological literature on language and identity, has the ability to set and define the company's identity in the host culture in which it is embedded.

Furthermore, as numerous writers (such as Holden 2002; Piekkari and Zander 2005; Vaara et al. 2005) note, language is a symbol of belonging, understanding, community definition and so forth-so that translation is also process of identity definition. We have already noted how, in New Malden, Korean identity focuses to some extent on shared language, and the degree of cultural assimilation and/or ability to get on in the host culture is symbolised (if not always assisted) by proficiency in English. Mrs Park's status as one of the most long-established members of the Korean community gives her some additional power in this regard. However, her role as someone who controls language gives her control over one of the key aspects of community definition. If language is crucial to the definition of identity, then translation and translators have an even more crucial role in the internal and external identity definition of communities.

Finally, this study suggests that identity, and the expression of identity, may play a greater role in international knowledge transfer than is normally suggested. My own ethnographic study of German expatriates has indicated that the expression and construction of identity plays a key role in the way in which they carry out their assignments, and whether they exchange or withhold information from local managers (Moore $2005 ; 2006$ ). Furthermore, in his study of transnational journalists, Hannerz speaks of them as surviving in transnational contexts through developing sets of "decontextualised knowledge," which can be recontextualised in different ways. This enables groups to be formed on the basis of shared bodies of knowledge and identity (1990: 246). As well as indicating that translation is an important part of the expression and formation of identity, the case of Mrs Park also suggests that identityrelated activities may be more important to business than has previously been considered.

\section{Conclusions}

This study is a necessarily brief, limited and experiential look at the role of the interpreter as a cultural intermediary negotiating identity and power relations in international business activities. However, one can nonetheless draw some interesting conclusions from the data. Firstly, they 
suggest that individuals who are liminal may hold a degree of power in terms of the role they have in mediating and transmitting discourses of identity, a fact which has frequently been overlooked in favour of a focus on more prominent individuals. Secondly, the data suggest that such processes of transnational identity definition, and the individuals who participate in them, are influential in the definition of self, other and community. Finally, they point to methodological issues for anthropologists, and others, working wholly or in part with translators as part of their research on transnational businesses (see also Chapman, Clegg and Gajewska-DeMatteos 2004).

The case of Mrs Park also suggests directions for future research. More such case studies are needed to broaden and expand earlier studies on the role of translators and interpreters in identity definition, particularly as Mrs Park was the only translator in our sample for the pilot study, and her experiences bear comparison with those of others. While the life-history method does provide rich data, it could also be argued that it creates bias in other ways, and thus should be used with caution in terms of drawing conclusions (Hammersley 1998: 8). The fact that identity played such a strong role in the conducting of business in this study also suggests that more studies of identity in transnational cultures are needed. Additionally, studies of the community embeddedness of corporations (as in Hill and Cassil 2004) could draw on such research, since translators are one of the ways in which corporations can interact with the host culture in situations where a common language is limited or lacking. Comparative studies of translators in other communities, and/or of the role of the bicultural youth (as in Goodman 1993, Moore 2007) in cross-cultural mediation, or more conventional, less individual-focused studies, are also worth carrying out to develop this project's findings.

In sum, then, this study develops our understanding of the social and power dynamics of translation in international business ventures: to view it as a site of transnational negotiation. The case of Mrs Park further contributes to theory about knowledge, discourse, language and power in that it suggests that translation also has a strong element of power relations, not only in terms of the transmission and withholding of information, but of the translator's ability to shape and define different identities and the relations of different organisations to each other. The translator's position as liminal individual and boundary spanner also allows him or her an ambiguous type of power, to stand between organisations and interpret them to each other. Translation thus involves power relations in terms of the control of knowledge and symbols, and interpretation in both the literal and figurative senses, making it a site of status and identity negotiation of great importance in organisations. 


\section{References}

Alavi, M., Kayworth, T. R., and Leidner, D. E. 2005/6 'An empirical examination of the influence of organizational culture on knowledge management practices.' Journal of Management Information Systems 22 (3): 191-224.

Angelili, C.V. 2004 Revisiting the interpreter's role: A study of conference, court, and medical interpreters in Canada, Mexico, and the United States. Amsterdam/Philadelphia: John Benjamins.

Black Elk, W., and Lyon, W.S. 1990 Black Elk: The sacred ways of a Lakota. New York: Harper and Row.

Blenkinsopp, J., and Pajouh, M.S. 2010 'Lost in translation? Culture, language and the role of the translator in international business.' Critical Perspectives on International Business 6 (1): 38-52.

Brannen, M. Y., and Doz, Y. L. 2012 'The languages of strategic agility: Trapped in your jargon or lost in translation.' California Management Review 54 (3): 77-97.

Burton, P., Dyson, K., and Ardener, S. (eds.) 1993 Bilingual women: Anthropological approaches to second language use. Oxford: Berg.

Buckley, P.J and Carter, M. 1999 'Managing cross-border complementary knowledge.' International Studies of Management and Organization 29 (1): 80-104.

Buckley, P.J and Carter, M. 2002 'Process and structure in knowledge management practices of British and US multinational enterprises.' Journal of International Management 8: 29-48.

Chapman, M., Clegg, J., and Gajewska-De Mattos, H. 2004 'Poles and Germans: An international business relationship.' Human Relations 57 (8): 983-1015.

Chun, B.G. 2009 'Firm's choice of ownership structure: An empirical test with Korean multinationals.' Japan and the World Economy 26: 26-38.

Clifford, J. 1986 'Introduction: partial truths.' In J. Clifford and G.E. Marcus (eds.), Writing culture: The poetics and politics of ethnography, pp. 1-26. London: University of California Press.

Cohen, A. P. 1985 The symbolic construction of community. London: Tavistock.

Cook-Gumperz, J. and Gumperz, J.J. 2002 'Narrative accounts in gatekeeping interviews: Intercultural differences or common misunderstandings?' Language and Intercultural Communication 2 (1): 25-36.

Czarniawska, B. 1997 Narrating the organization: Dramas of institutional identity. London: University of Chicago Press.

Czarniawska, B. 2004 Narratives in social science research. London: Sage. 
Dana, T. E. 1999 'Case studies: Korean restaurant in Christchurch.' British Food Journal 105 (1/2): 137-140.

Dhanania, K. and Gopakumaran, S. 2005 'Marwari business discourse: An analysis.' Journal of Asia Pacific Communication 15 (2): 287-312.

Douglas, M. 1966 Purity and danger: An analysis of the concepts of pollution and taboo. London: Ark.

Edwards, R., Temple, B., and Alexander, C. 2005 'Users' experiences of interpreters: The critical role of trust.' Interpreting 7 (1): 77-95.

Fairclough, N. 1989 Language and power. London: Longman.

Gabriel, Y. 2000 Storytelling in organizations: Facts, fictions, fantasies.

Oxford: OUP.

Van Gennep, A. 1960. The rites of passage, trans. Monica B. Vizedom and Gabrielle L. Caffee. Chicago: University of Chicago Press.

Gephart, R.P. 1978 'Status degradation and organizational succession: An ethnomethodological approach.' Administrative Science Quarterly 23 (4): 553-581.

Going Global 2003 Going global career guide 2003. www.goinglobal.com. Accessed 2 May 2007.

Goodman, R. 1993 Japan's "international youth": the emergence of a new class of schoolchildren. Oxford: Clarendon Press.

De Graaf, G. 2001 'Discourse theory and business ethics. The case of bankers' conceptualizations of customers.' Journal of Business Ethics 31: 299-319.

Gumperz, J.J. 1974 'Linguistic anthropology in society.' American Anthropologist N.S. 76 (4): 785-798.

Hammersley, M . 1998 Reading ethnographic research: A critical guide [2 ${ }^{\text {nd }}$ ed.]. Harlow: Addison Wesley.

Hannerz, U. 1990 'Cosmopolitans and locals in world culture.' In M. Featherstone (ed.), Global culture: Nationalism, globalization and modernity, pp. 237-251. London: Sage.

Harzing, A. W., and Feely, A. J. 2008 'The language barrier and its implications for HQ-subsidiary relationships', Cross Cultural Management: An International Journal 15(1): 49-60.

Hill, R. P. and Cassill, D. L. 2004 'The naturological view of the corporation and its social responsibility: an extension of the Frederick model of corporation-community relationships.' Business and Society Review 109 (3): 281-296.

Holden, N. J. 2002 Cross-cultural management: A knowledge management perspective. London: Financial Times/Prentice Hall.

Holden, N. J. and von Kortzfleisch, H. 2004 'Why cross-cultural knowledge 
transfer is a form of translation in more ways than you think.' Knowledge and Process Management 11 (2): 127-138.

Holmer-Nadesan, M. 1996 'Organizational identity and space of action'. Organization Studies 17 (1): 49-81.

Iyer, G.R. and Shapiro, J.M. 1999 'Ethnic entrepreneurial and marketing implications for the international economy.' Journal of International Marketing 7 (4): 83-110.

Jeffery, P. 1976 Migrants and refugees: Muslim and Christian Pakistani families in Bristol. Cambridge: Cambridge University Press.

Lee, Y.I., and Trim, P.R.J. 2008 'The link between cultural value systems and strategic marketing: Unlocking the mindset of Japanese and South Korean managers.' Cross Cultural Management: An International Journal 15 (1): 62-80.

Levi-Strauss, C. 1974. Structural anthropology. New York: Basic Books.

Osman-Gani, A. M. 2000 'Developing expatriates for the Asia-Pacific region: a comparative analysis of multinational enterprise managers from five countries across three continents.' Human Resource Development Quarterly 11(3): 213-235.

MacDonald, S. and Piekkari, R. 2005 'Out of control: personal networks in European collaboration.' $R$ and D Management 35 (4): 441-453.

Marschan-Piekkari, R., Welch, D. E., and Welch, L. S. 1999 'In the shadow: The impact of language on structure, power and communication in the multinational.' International Business Review 8(4): 421-440.

Martin, J. 2002 Organizational culture: Mapping the terrain. London: Sage.

Merilainen, S., Tienari, J., Thomas, R., and Davies, A. 2004 'Management consultant talk: A cross-cultural comparison of normalizing discourse and resistance.' Organization 11(4): 539-564.

Moore, F. 2005 Transnational business cultures: Life and work in a multinational corporation. Aldershot: Ashgate.

Moore, F. 2006 'Strategy, power and negotiation: Social control and expatriate managers in a German multinational corporation.' International Journal of Human Resource Management 17 (3): 399-413.

Moore, F. 2007 'The German School in London, UK: fostering the next generation of national cosmopolitans? ' In: A. Coles and M. Fechter (eds)., Gender and family among transnational professionals, pp. 85-101. London: Routledge.

Moore, F. 2011 'Holistic ethnography: Studying the impact of multiple national identities on post-acquisition organizations.' Journal of International Business Studies 42 (5): 654-671.

Mikkelson, H. 2001 'Interpreter ethics: A review of the traditional and electronic literature.' Interpreting 5 (1): 49-56. 
Negus, K. 2002 'The work of cultural intermediaries and the enduring distance between production and consumption.' Cultural Studies 16 (4): 501-515.

Nixon, S. and DuGay, P. 2002 'Who needs cultural intermediaries?' Cultural Studies 16 (4): 495-500.

Parkin, D. 1984 'Political language.' Annual Review of Anthropology 13: 345-365.

Peltokorpi, V. 2010. 'Intercultural communication in foreign subsidiaries: the influence of expatriates' language and cultural competencies.' Scandinavian Journal of Management 26: 176-188.

Piekkari, R. and Zander, L. 2005 'Preface: Language and communication in international management.' International Studies of Management and Organization 35 (1): 3-9.

Rudvin, M. 2004 'Professionalism and ethics in community interpreting: The impact of individualist versus collective group identity.' Interpreting 9 (1): 47-69.

Sanyal, R., Napier, N. K. and Smith, B. 2007 'The parting gift.' Thunderbird International Business Review 49 (5): 619-631.

Sperber, D. 1974. Le symbolisme en general. Paris: Hermann.

Thomas, R. and Linstead, A. 2002 'Losing the plot? Middle managers and identity.' Organization 9: 71-93.

Usunier, J.-C. 2011 'Language as a resource to assess cross-cultural equivalence in quantitative management research.' Journal of World Business 46(3): 314-319.

Welch, D. E., Welch, L. S., and Piekkari, R. 2005 'Speaking in tongues: The importance of language in international management processes.' International Studies of Management and Organization 35(1): 10-27.

Williams, P. 2010 Special agents: The nature and role of boundary spanners. Paper presented to the ESRC Research Seminar Series Collaborative Futures: New Insights from Intra- and Inter-Sectoral Collaborations. Birmingham: University of Birmingham, February 2010 Vaara, E., Tienari, J., Piekkari, R. and Santti, R. 2005 'Language and the circuits of power in a merging multinational corporation.' Journal of Management Studies 42 (3): 595-623.

Ybema, S., Yanow, D., Wels, H. and Kamsteeg, F. 2009 'Studying everyday organizational life.' In S. Ybema, D. Yanow, H. Wels and F. Kamsteeg, Organizational ethnography: Studying the complexity of everyday life, pp. 1-20. London: SAGE. 
Fiona Moore is a Reader at Royal Holloway University of London. She has a DPhil from Oxford and has conducted research with BMW and DGBank. Her recent research includes a study of sojourner adjustment among Korean entrepreneurs in London, in collaboration with colleagues at Kingston University, a study funded by the Nuffield Foundation on the social networks of Taiwanese businesspeople in the UK and Canada, and a study of corporate and national culture in Tesco in collaboration with researchers at INSEAD and Anglia Ruskin university. Her research has been published in such journals as JIBS and Global Networks, and she is the author of the monograph Transnational Business Cultures: Life and Work in a Multinational Corporation. She can be contacted at fiona.moore@rhul.ac.uk and her website is at www.fionamoore.com 